\title{
The Princess Turned Prince.
}

\section{Transsexual Metamorphosis in the "Ileana SÂmziana" FaIRy Tale}

\author{
KRISZTINA BIANKA KOCSIS*
}

\begin{abstract}
Seeing that the majority of folk tales feature a male protagonist, the "Ileana Sâmziana" fairy tale, collected by Petre Ispirescu, represents a deviation from this heroic archetype by focusing on the emperor's daughter, who would become Prince Charming. Circumscribed to the ATU 514 folk motif, i.e., change of sex, it depicts gender fluidity reminiscent of cross-dressing in pubertal rites of passage. Based on these premises, the present paper closely analyses the process of transsexual metamorphosis of the main character. Ultimately, it is aimed to expose any resemblance to traditional formative discourses on masculine social values and determine whether the emperor's daughter should be regarded as a true feminine and /or a heroic figure.
\end{abstract}

Keywords Fairy tale, rite of passage, androgyny, cross-dressing, change of sex.

\begin{abstract}
"Once upon a time" - that is all it takes for us to be bound by the spell of fairy tales, which permeates every aspect of our lives, on account of the two-way influence between our world and secondary representations (fictional worlds). As a direct consequence of the didactic uses of storytelling, the fairy tale hero is, generally speaking, promoted as an example worth following by the reader, even turned into a fictional benchmark of moral conduct within folk imaginary. In parallel, the ethical coordinates which govern our world are conveyed in literary form, mirrored in the fictional universe that features the hero's quest, so that the real and fairy tale realms are indeed mutually supportive.

In an overview of the gender identities present in fantastic stories, one cannot but notice that the majority of the heroic instances are masculine in quality,
\end{abstract}

* Babeş-Bolyai University, Cluj-Napoca. krisztina_10@yahoo.com.

DOI: 10.26424/philobib.2021.26.2.10 
appearance, and ontological essence, with the female character functioning as its complement. To insist on this issue, two main configurations emerge from such a simplistic conceptualization of femininity within the pages of fairy tales: one envisioned in an apparently flattering light (woman as the epitome of beauty, yet limited to a passive state - think of the princess in distress, Iliane of the Golden Tresses) and the other one, formulated in overtly derogatory terms (woman endowed with evil powers, autonomy- see the archetype of the witch, the genie's mother). Within this frame of reference then, what other options are there left for fairy tale heroines? Thus, the premises of my research reside precisely in the search for an alternative identity to the above-mentioned diptych of femininity and a suitable model is found in the ATU 514 folk motif from the Aarne-Thompson-Uther catalogue. ${ }^{1}$ This umbrella term covers a broad category of folk narratives containing a change-of-sex scene; most commonly it follows the female-to-male shift.

Straying away from the formula of male heroes and female victims, such stories represent the focal point of this essay, owing to the fact that they promote a heroic prototype which proves subversive on various levels, namely the emperor's youngest daughter, who, although anonymous at first, becomes by the end Făt-Frumos himself, akin to Prince Charming. The fluidity of the girl-boy's identity imposes gender analysis as one of the approaches, which is in fact aligned with current socio-political debates, but also the dominant research tendency to revisit and reconsider archaic cultural products. By juxtaposing the old text with present-day concerns, this way of reading illuminates new interpretative possibilities and at the same time contributes to the propagation of the story throughout numerous paradigm shifts. With this in mind, the ATU 514 motif represents a valuable material in order to unveil less explored facets of traditional folk imaginary, since, at least at first glance, this fairy tale type suggests not only the possibility of transgressing one's social limitations (which is the core of most folk rags-to-riches stories with agrarian notes ${ }^{2}$ ), but also one's gender and even sexual identity. In this regard, one objective of this investigation is, on a larger scale, to problematize the very idea that there is indeed a fascination for gender transgression even in a culture that we are inclined deem ultra-traditional, such as the folk culture which produces and consumes fairy tales.

\footnotetext{
${ }^{1}$ Antti Aarne and Stith Thompson, The Types of The Folktale. A Classification and Bibliography (Helsinki: Suomalainen Tiedeakatemia Academia Scientiarum Fennica, 1973), 182, https://archive.org/details/ffcommunications0000unse/page/n5/mode/2up (Accessed 15 September 2021).

2 For a concise review of the historical evolution of fairy tales from their popular prototypes up until today's cult movies and multimedia adaptations see Jack Zipes, Breaking the Magic Spell. Radical Theories of Folk and Fairy Tales, revised and extended (University Press of Kentucky, 2002) or Jack Zipes, Why Fairy Tales Stick: The Evolution and Relevance of a Genre (Routledge, 2006).
} 
With attention to the Romanian literary space, the body of work under scrutiny here is the version collected by Petre Ispirescu, entitled "Ileana Sâmziana". ${ }^{3}$ Given these premises, the present paper seeks to explore some points of convergence and divergence between this particular rendering of the ATU 514 motif and the corpus of cliché coming-of-age tales revolving around a male hero. The main question raised is the following: can a female character such as the emperor's daughter be a heroic figure in a traditional framework while also keeping her femininity? With that end in view, prominence is given to expressions of femininity and masculinity, the gradual departure from what has been biologically and culturally prescribed and the creation of a new identity throughout the initiatory journey. Thus, the analysis of this alternative female type is based on certain narrative elements with a direct bearing on gender assessment- typical fairy tale triads, preference for symmetry, heroic trials, character prototypes, masculine and feminine influences, just to name a few and in a broader sense, it takes into account the didactic uses of this folk genre, the features of folk imaginary, the ritualistic tests, the psychological and physiological transformations undergone by the female protagonist.

To begin with, one of the most frequently cited uses of fairy tales is related to the pedagogic function of the act of storytelling in its primitive form. Part of the collective artistic property, it is first developed as a synthesis so to speak of the community's experiences, thus serving as an instructive resource via exemplary discourse. ${ }^{4}$ It is through the supernatural element that such narratives, whether oral or written, reflect the current social situation, establish the norm, and even prescribe ethical behaviours. For the sake of easily decoding the message, the scenarios are reduced to key moments and along with this, the characters obey a simple psychology, divided in good and evil, hero and villain, black and white, without grey, liminal areas- which pertain rather to a postmodern worldview.

Another essential aspect of reading and interpreting folk narratives in general is related to their origin, well before the agrarian societies, for fairy tales have long been viewed as an extension of myths, surviving multiple paradigm shifts as part of

\footnotetext{
${ }^{3}$ There are numerous translations to English of the Romanian ATU 514 tale type, such as "The Princess Who Would be a Prince", "Iliane of the Golden Tresses", "The Princess in Armour", "The Girl Who Pretended to be a Boy" etc. In keeping with the Romanian version, the fairy tale will be here referred to as "Iliane of the Golden Tresses", whereas any quotations given to drive home an argument will be taken from Rea Ipcar and Julia Collier Harris (trans.), "The Princess Who Would be a Prince; or Iliane of the Golden Tresses," in The Foundling Prince, \& Other Tales: Translated And Adapted From the Roumanian of Petre Ispirescu (Boston: Houghton Mifflin Company, 1917), 241-284.

${ }^{4}$ See Ovidiu Bîrlea, Mică enciclopedie a poveștilor românești [Small Encyclopedia of Romanian Stories] (București: Editura științifică și enciclopedică, 1976) or Viorica Nișcov, A fost de unde n-a fost. Basmul popular românesc [Once Upon a Time. The Romanian Folk Tale] (Bucharest: Humanitas, 1996).
} 
the collective imaginary. The connection between the two is based on the fact that both recount extraordinary events, featuring exemplary characters, which undergo a process of spiritual initiation and have a significant impact on the reader at the level of his subconscious. ${ }^{5}$ More often than not, the folk tale plot revolves around social situations, common problems, and their solutions, while the optimistic ending ensures a happy life here, on earth, and not in the realm of Greek deities. ${ }^{6}$ As compared to its mythical counterpart, the fairy tale protagonist presents itself as a role model that is much more attainable for the reader, as it embodies a less idealized heroic figure, which in turn, means that it feels closer to the everyday man. Insofar as the present paper traces rather the heroine's evolution from one ontological state to another, from one gender to another, and not necessarily the mythical roots of this text, I will not insist on this subject. Yet, these are still elements worth considering when reading the story of the girl who pretends to be a boy and then becomes one, since the emperor's daughter embodies the above emphasized aspects.

In a general look on fantastic stories, an increasing number of studies have claimed the existence of a common imaginary basis, shared by most Indo-European cultures. Such a view has been prompted by the discovery of similar folk elements in communities observed in the same developmental stage, in spite of a lack of direct communication between them. As a consequence, the originality of a people such as the Romanians rests rather on in their ability to recycle, combine and recontextualize widely-circulated symbols and motifs. ${ }^{7}$ Such intercultural exchanges are evident even in the case of the ATU 514 motif- albeit less frequently encountered than other themes- since multiple versions from Romania, Serbia, Albania, and Russia ${ }^{8}$ reiterate the same main points of the plot. To detail, the tale opens with the emperor's crisis, having only three daughters and no sons, among which it is always the youngest who embarks on a mission to pay her father's debts to another emperor, surpasses a series of tests disguised in male clothes, and the transsexual transformation occurs as a punishment inflicted on the heroine for having stolen a sacred object. ${ }^{9}$

\footnotetext{
${ }^{5}$ See Mircea Eliade, "Appendix I: Myths and Fairy Tales," in Myth and Reality, trans. Willard R. Trask (New York: Harper and Row, 1963) or Bruno Bettelheim, The Uses of Enchantment. The Meaning and Importance of Fairy Tales (New York: Vintage Books, 2010).

${ }^{6}$ Bruno Bettelheim, 55-56.

7 Viorica Nișcov, A fost de unde n-a fost [Once Upon a Time], 91.

8 Maja Pan, "Introduction to the Analysis of Gender in the ATU 514 Fairy Tale Type on Examples from the Balkans," Studia Mythologica Slavica XVI (2013): 165-186.

${ }^{9}$ Cristian Cioancă, "Motivul fecioarei războinice în basmul fantastic românesc" ["The Virgin Warrior Motif in the Romanian Fairy Tale"], Memoria Ethnologica XV, no. 54-55 (January-June 2015): 52-55.
} 


\section{The emperor's daughter}

Before assessing the gender identity of the character during and after this process, let us take a closer look at some factors at play. From the very first lines of the "Ileana Sâmziana" text, as recorded by Petre Ispirescu, the biological mother of the three princesses is absent, much like in other fairy tales, which leaves the children lacking a proper female guide in their psychological development. Nonetheless, her place is not filled by a surrogate or an evil stepmother. Instead, the three daughters will have to grow up without a female mentor and signs of femininity are to be found in typical group activities within the household, which will be later on invoked by their own father as part of the oldest and the middle children's punishments for having failed their first test: "Rest at home, my daughter. Busy yourself with your spindle, ${ }^{10 "}$ "Rest at home, my daughter. Busy yourself with your broidery and with the cooking of tarts. ${ }^{11 "}$ Also, the female characters are exclusively referred to by their social status, instead of given names- once again resembling other fairy tales they are defined as the emperor's children, that is to say, in relation to a paternal (masculine) referent, while their age is the only criterion of differentiation: the youngest, the middle, and the oldest daughter.

As a matter of fact, the father too falls short in the role model department, as an elderly man, deficient in physical strength and courage, things he once had as a young hero himself. No longer capable of defending his land and subjects, he is forced to yield to the outrageous demands of the emperor of the neighbouring land, i.e., to send one of his (non-existent) sons to serve at his court. Preoccupied with his political issues, their father becomes more concerned with not having a male heir than the wellbeing of his own children, deprived of a maternal figure. All in all, this urgency to pay a debt that is impossible to settle because the old emperor has only three daughters and no sons - can be read as a mere pretext to prove the inadequacy of the princesses in the affairs of men, more precisely of rulers. Diplomatic interactions can under no circumstances be carried out by female emissaries, nor is there the option of negotiating, explaining the situation to the neighbouring emperor - as the reader's logic would dictate, yet, we are asked to suspend our disbelief and go along with the fairy tale logic. To add to this, the words uttered by the father - "Only a brave lad can deliver me, a son who could wield arms, flourish the sabre, and charge like a lion upon dragons ${ }^{12 "}$ further stress this male anxiety of the man with no male heirs to the throne and the disgrace generated by this failure, which in turn is the catalyst of the events about to take place.

\footnotetext{
10 Petre Ispirescu, The Foundling Prince, \& Other Tales, 248.

11 Petre Ispirescu, 248.

12 Petre Ispirescu, 243.
} 
Already, female inferiority and the advantages of the opposite sex are perceived by the three daughters, who are eager to relinquish the comfortable lifestyle within the regal court only to save their father's honour and attempt to pass the test of courage set by the emperor, who is waiting for them at a bridge self-metamorphosed into a wolf. This marks the first steps of the initiatory process, in accordance with the coordinates of primitive rites of passage, containing details such as the bridge as a liminal space, the father as the master initiator, the reversible nature of the metamorphosis, the failure of the oldest and the middle child and their return to their previous ontological state, the repetition of the tests until the worthy subject is found.

One could interpret this passage as indicative of the cliché of female rivalry, with the three daughters competing for their father's love; yet, as above stated, the older sisters prove to be insufficiently equipped for this quest biologically and spiritually speaking - as opposed to the youngest. Something important to realize at this point is that the objective of the bridge trial is twofold: on the one hand, it tests the subjects' courage - keep in mind, a masculine attribute - and on the other hand, it questions and challenges their feminine identity. That is why the only way to preserve and/or regain it is by leaving behind such heroic aspirations and returning to the gender role which was biologically assigned to them in the first place- that is the course taken by the oldest and the middle child. Henceforth, the series of adventures that are about to follow will progressively lead the youngest daughter towards another ontological state, in fact, another gender identity, and this transformation will be completed together with the last test surmounted by the neophyte.

Besides the absent maternal figure and the elderly father, another point of reference for the emperor's daughter in her gender initiation is the helpful horse, a recurring character, especially in Romanian folk and fairy tales. In stories centred on a male protagonist often the main function of this magical animal is that of the advisor and apt strategist, embodying the archetype of wisdom. This kind of intuitive thinking will then be used to instruct, direct and adjust the novice's actions, who lacks sufficient empirical experience. In fact, the distrust some critics have in the hero's self-sufficiency, in general, is partly attributed to this need for a helper's intervention throughout the quest. At the same time, it explains the aforementioned demystification of the fairy tale character, who is demoted from a god-like status to the ontological state of flawed humanity, as the uninitiated man who needs guidance at every step of the way and becomes in this way more relatable in the eyes of the reader. ${ }^{13}$ Reconsidering the horse's role from a psychological standpoint,

13 Maria Popa, "Male and Female Prototypes in Romanian and French Fairy Tales," in Convergent Discourse. Exploring the Contexts of Communication, eds. Iulian Boldea and Dumitru-Mircea Buda (Târgu-Mureș: Arhipelag XXI Press, 2016), 703. 
the animal also epitomizes the sum of fatherly teachings. Given the fact that the emperor's authority can no longer operate outside the limits of his land, the stallion serves as a prolongation of the paternal figure, offering the correct solution to each obstacle or tribulation faced by the neophyte. Continuing this line of thought, the fact that at some point the horse which used to belong to the heroine's father is exchanged for a younger one, named Sunbeam (Galben-de-Soare), also signifies an epistemological progress. If the former directly provides the right answers, the second helper urges the transvestite girl to first analyse, assess the situation and only then proceed. To put it differently, the new stratagem corresponds to the adolescent impulse overtly defying paternal lessons, to gain dependence, distance one's self from the mental space of family, and develop one's own axiological system, because the former one is no longer viable in the following stages of the initiatory journey. ${ }^{14}$

Continuing the investigation of the aspects that tip the scale towards one gender or the other, the way the trials are constructed is equally relevant. Closely following the template of most Romanian fairy tales focused on a male hero, the tests are organized in a linear, symmetrical, tripartite manner and reflect the phases of gender metamorphosis. Once the heroine enrols in the mission, what follows is a series of three instances meant to examine the neophyte's bravery, other three gender trials and finally her gender identity is anchored after three more obstacles.

Referring to the bridge trial inserted in the pre-initiation stage of the ATU 514 tale type, Ovidiu Bîrlea underlines the mandatory nature of this additional step when it is a girl dressed as a boy the one who embarks on this quest. ${ }^{15}$ To clarify, the three daughters, being trained rather for domestic chores, need to be tested for their courage, determination, and endurance, whereas if the neophyte were a young man, he would already have proven himself worthy and have spent the majority of his life preparing for this precise objective. Also in this preparatory stage, a departure from the prior gender identity is symbolized through specific clothing choices: after having obtained her father's old horse, typically feminine accessories are replaced by simple dress and war-armour so as to pass as a boy: "she put on clean clothes, yet without any jewellery. ${ }^{16 \prime \prime}$

\footnotetext{
14 V. Preda și E. Cocoroadă, "Adolescent Psychological Development in Romanian Fairy Tales," Bulletin of the Transilvania University of Braşov VII: Social Sciences - Law 9 , no. 2 (2016): 194. 15 Ovidiu Bîrlea, Mică enciclopedie [Small Encyclopedia], 312.

16 Petre Ispirescu, The Foundling Prince, 252. While this English translation offers more details regarding the preparatory stage, the original text goes like this: "își luă niște haine curate, dară fără podoabe" ["she put on clean clothes, yet without any jewelry"] (My translation. If not attributed to another translator, all quotes in Romanian have otherwise been translated by the author of this essay) in Petre Ispirescu, "Ileana Sâmziana," in FătFrumos cu părul de aur. Basme populare românești, vol. II, ed. loan Șerb (Bucharest: Editura Pentru Literatură, 1967), 129.
} 
In large measure, "Iliane of the Golden Tresses" replicates the structure of primitive masculine initiation, starting from the novice's departure from his natal space, both geographically and mentally speaking, to solve a problem until world balance is restored and the initiated man returns - the main difference being here the female sex camouflaged in male disguise. To emphasize, the courage test which has each of the three daughters confronted with their father transformed in a fierce animal integrates the bridge motif as a transitional space in folk imaginary, implying a sense of both continuation and interruption. On the one hand, it closes the borders of the familiar world and opens the horizons of a strange world, filled with all sorts of mysteries, and on the other hand, passing from one side of the river to the other suggests the transition from one form of existence to another, i.e., reaching a higher ontological status. Hence, reading this scene through an anthropological lens- in line with Arnold van Gennep's seminal work ${ }^{17}$ - the details earlier highlighted argue for a true rite of passage, whereby the transvestite heroine crosses a symbolic threshold when she crosses the three bridges.

Point often overlooked, the tripartite bridge-test entails three different construction materials (brass, silver, gold) and three totemic animals (wolf, lion, dragon). Undoubtedly, this crescendo of metals carries alchemic connotations, with the most precious metals representing spiritual elevation. After the bridge made of brass come the silver and the golden one and Jean Chevalier, together with Alain Gheerbrant, attributes these two materials antithetic nuances: if silver is related to the lunar, cold, feminine domain, ${ }^{18}$ gold stands for the diurnal, warm, masculine principle. ${ }^{19}$ In this reading, the instruction process requires not only for the neophyte's identity to be neutralized - inferred by the fact that the three daughters' names are omitted-but also for it to merge within the same body the two opposing Jungian concepts, animus and anima, in order to (re)gain a sense of completeness. Parallel to the varying bridges, the emperor himself takes on three animal forms, with a similar progression from a common animal, the wolf, to the lion, which is less likely to be encountered in everyday life, up until the twelveheaded dragon, with slim chances of being seen in a normal setting. To extrapolate, the triple animal obstacles also stimulate a sense of immersion in the fictional realm, transporting the reader from the real, the plausible (the wolf) to the imaginary, incredible world of the dragon.

\footnotetext{
17 See Arnold van Gennep, Rites of Passage, trans. Monika B. Vizedom and Gabrielle L. Caffee (Chicago: University of Chicago Press, 1960).

18 Jean Chevalier and Alain Gheerbrant, Dictionnaire des symboles. Mythes, rêves, coutumes, gestes, formes, figures, couleurs, nombres (Paris: Editions Robert Laffont et Editions Jupiter, 1982), 75.

19 Jean Chevalier and Alain Gheerbrant, 706.
} 


\section{The girl-boy}

Moving on to the next phase of the initiatory journey, the neophyte's identity has already been neutralized and the possession of the opposites is noticeable whenever the horse-advisor's intervention is needed to readjust the transvestite's feminine behaviour in order to conform with the masculine norm, i.e. so as not to deviate from the main purpose of the task at hand: "But the horse rescued her from the spell of springtime, and her gave sage counsels and good advice, hastening his step without wandering to right or left. She learned from him that knights do not seek repose until after the victory. ${ }^{20 \prime \prime}$

After the test of bravery and the official severance from her family, the androgynous character meets, on her way to the castle, two genii, caught in a seemingly unresolvable conflict for over nine years. This encounter is by no means accidental, since it prompts another trial, this time intended to test the subject's decision-making skills. To settle this discord, the girl-boy is summoned to choose which genie will be victorious, respectively which one will live and which one will die. Due to the lack of details in their description, the two genii are quasi-identical and for this reason, favouring one over the other depends neither on their virtues nor their actions, but rather on the reward promised to the heroine, who plays judge. As expected, the horse's recommendation supports the genie guaranteeing to arrange for her to get a new equine helper or simply put, to choose what will be more advantageous in her future endeavours.

The constant pressure exerted on the heroine by the magical horse to deny, even repress her feminine impulses might not have cauterized so far the anima side of her psyche, however, the threefold gender/sex examination will definitely compel the emperor's daughter to perform masculinity repeatedly until dissimulation comes to be true. On this occasion, the one suspicious of the protagonist's sex and the one soliciting the trial is the genie's mother, who exemplifies another side of the fantastic feminine. Prevalent in Romanian fairy tales, she is characterized by intuition exaggerated into paranoia and becomes a monstrous caricature of maternal protection. What is more, the genie's mother belongs to the category of already initiated female characters, in contrast to the young heroine, and hence, she can intuit the real sex of her son's saviour, unlike the gullible genie.

Needless to say, the tests themselves are heavily reliant on superstitions, according to folk mentality, such as the one involving two flower bouquets left over night by her and the genie's bedside. It is believed that if by sunrise, the flowers are withered, it is an indication of virility, that the subject is indeed a man, whereas if they are intact, this is connected to female fertility; but of course, the bouquets are exchanged in order to mislead the genie's mother. As it turns out, her suspicions are

20 Petre Ispirescu, The Foundling Prince, 255-256. 
not confirmed even after the following two tasks, much to her disappointment, thanks to the plan devised by the girl in disguise with the assistance of her trusty horse. During this, what is required of the androgyne is self-control when faced with beautiful flowers and ornate weapons, with the aim of convincingly simulating masculinity and along with this, the risk of abandoning her femininity.

With a focus on the ambivalent sexual and gender identities, the opening scene features the protagonist circumscribed to femininity, but throughout the quest there is no denying that the two cosmogonic forces coexist in one body. This is achieved through the act of cross-dressing, which carries, above all, mythical implications, with reference to the idea of coincidentia oppositorum or better said, similarly to the hermaphrodite deities pertaining to the ancient pantheon, with Dionysos as the prime example $e^{21}$ - here, this duality is viewed in a positive light. Correspondingly, this two-in-one structure can be found even in cosmogonic narratives, envisioning the primordial human as having both masculine and feminine characteristics, namely, as an androgynous being, on the grounds of the sphere as a symbol for perfection, completeness. A possible explanation for this type of conceptualization derives from the archaic belief in the immense spiritual energy provided by the union of two in one, as noted by Mircea Eliade: "one cannot be anything par excellence unless one is at the same time the opposite. ${ }^{22 "}$ In the light of this idea, the neophyte's fluid identity in the "Iliane of the Golden Tresses" fairy tale functions as a precondition to gain access to the unity, the lack of differentiation, back in that mythical in illo tempore, to grasp both possibilities of being, of gender in this case, and ultimately, to restore, even if only temporarily, the nostalgic state of spiritual equilibrium preceding the moment of Creation.

Shifting our attention back to the plotline, there is a tacit conflict between the girl in disguise and the rest of the young men serving at the court of the sovereign emperor, on account of the affinity of the latter to the newcomer, with no one suspecting the crossdresser's true self. In this context, a detail worth mentioning concerns the method of conflict resolution applied by the protagonist: instead of some overt demonstrations of manhood, bravery, physical force or wielding phallic objects, the emperor's daughter, on the contrary, prepares a special meal for them as a means to win her peers' respect. Since cooking is largely deemed a domestic practice, this might be one last revisitation to the female gender previously performed, before complete immersion into the opposite sex and gender.

Furthermore, the ensuing series of impossible tasks requested by the emperor also includes delivering to him Iliane of the Golden Tresses, activating the motif of conquering and/or defeating the untouchable body, as read by Cristian

21 See Mircea Eliade, Mephistopheles and the Androgyne: Studies in Religious Myth and Symbol, trans. J. M. Cohen (New York: Sheed and Ward, 1965).

22 Mircea Eliade, 110. 
Cioancă. ${ }^{23}$ As for the ways of obtaining the princess, ${ }^{24}$ physical beating is present, for example, in a tale collected by lonel Oprișan, where not only does the emperor's youngest son win his bride by ways of whipping her, but there is a certain condition to abide by in view of their marriage. The future bride is forced to abandon half of her identity (see the title of the tale): "On one condition you will be a fitting wife: you will no longer be brave, ${ }^{25}$ " so that she cedes her sword, yet she shall maintain her intellectual superiority throughout the following events. But Petre Ispirescu's version of the ATU 514 tale proposes an alternative scenario, different from those comprised in Cioancă's classification. Explicitly, the girl in armour rescues the princess from another genie and then confronts the fury of his mother multiple times. At this point, not only the result itself is essential - saving the female character - but also the deceitful approach taken by the hermaphrodite heroine the double kidnapping of lliane from the genie, her prior kidnapper, and this represents the first clear instance in which the moral laws are violated, that is why punishment is bound to come.

\section{Prince Charming}

The girl-boy continues then to act as her sovereign's emissary, taking his place even in the three tests demanded by the future bride, lliane, as marriage conditions given to the emperor, which are afterward assigned to the main character. I shall not dwell on this set of tasks too much, since they do not have a major bearing on the discussion at hand, with the exception of the final one: stealing a sacred item, after which the androgyne's identity is restructured because of a curse. As a result, gender is no longer a fluid concept, but is stabilized and at the same time the body undergoes significant changes, in such a way that the simulated (masculine) role and the real (feminine) self are finally reconciled. At a textual level, there are certain details to note in the following lines, particularly the act of stealing, the curse viewed as either a punishment or a reward, external and internal metamorphosis, the prevention of a hermaphroditical and homoerotic ending, the success of the archetypal wedding.

On the one hand, divine anger is indeed a plausible explanation for the words echoed in the fairy tale universe as soon as the vase of holy water goes

23 See Cristian Cioancă, "Înfrângerea și/sau cucerirea corpului de neatins din basmul fantastic românesc," ["The Motif of Conquering and/or Defeating the Untouchable Body in the Romanian Fairy Tale"], Studia Universitatis Petru Maior. Philologia, no. 17 (2014): 140-155.

${ }^{24}$ Cristian Cioancă, 141.

25 Original text: "C-o singură condiție vei fi soție dreaptă: nu ai să mai fii vitează" in lonel Oprișan, "Frumoasa Lumii, Viteaza Lumii" ["The Most Beautiful, the Bravest"], Basme fantastice românești, second volume, second edition, revised (Bucharest: Vestala, 2005), 22. 
missing: "May he become a woman if he is a man, or a man if he is a woman! 26 " To elaborate on this, folkloric moral codes dictate that the heroine should be sanctioned after having taken the baptismal vessel "near the river Jordan" ${ }^{27 "}$ and for not obtaining it through honest efforts, because such a profane act openly disregards the fundamental ethical norms. In any case, the androgyny motif is materialized through the curse uttered by the hermit or nun in certain versionsanother initiated character, carrying mytho-folkloric connotations. In this manner, the catalyst of the resexualization process is words and their power of actualization: once verbalized, the sex/gender is decided, which means that what has been up to this point make-believe is converted into actual truth.

On the other hand, beneficial effects of this particular curse include the possibility of marrying Iliane of the Golden Tresses, the fairy tale prototype of femininity, together with the protagonist taking her/his rightful place on the throne. The most compelling evidence of this interpretation lies in the characters' failure to react to the metaphysical event, like attempting to reverse the spell, as they seem to tacitly accept the new state of being. Tracing the psychosocial evolution of the fairy tale hero, Bruno Bettelheim comes to the conclusion that the ending necessarily brings the reconciliation of the external conflict, but also the internal conflict within the character, a misfit at first, for "once the fairy tale hero has achieved his true identity at the story's ending (...) he is happy the way he is, and no longer unusual in any respect. ${ }^{28 "}$ "From another perspective, the curse operates as a literary device employed to resolve the erotic and marital crisis and in keeping with the patriarchal values, it emphasizes the advantages of masculinity even more poignantly than at the beginning of the initiatory quest. Consequently, the apparently fateful metamorphosis can indeed be read in a positive sense: it is the prize received after successfully completing the quest. Tilting the gender scale towards masculinity not only rectifies the uncomfortable image of the hermaphrodite, but also cancels the potentially homoerotic union between the two female characters, the emperor's daughter and Iliane of the Golden Tresses ${ }^{29}$ - an inadmissible couple within traditional heteronormativity.

Be that as it may, in the previous stages of the plot the heroine's main objective was to impersonate a man as best as possible, while in the final scenes the task itself to take the vessel prevails. The sacred object is stolen not for its own sake, but with a view to what it will bring about: economic affirmation, romantic fulfilment

\footnotetext{
26 Petre Ispirescu, The Foundling Prince, 281.

27 Petre Ispirescu, 279.

28 Bruno Bettelheim, The Uses of Enchantment, 78.

29 Interestingly enough, another Romanian variant of the ATU 514 folk motif entertains the possibility of a lesbian union between the two - see Ovidiu Bîrlea, "Cu un împărat" ["About an Emperor"], in Antologie de proză populară epică, second volume: Basme fantastice (Bucharest: Editura pentru literatură, 1966), 149-157.
} 
and beyond everything, the end of the initiation cycle. Important to note, the change of sex happens when least expected ${ }^{30}$ and its effects are irreversible. In agreement with the internal logic of fantasy, this transsexual mutation certainly affects the character mentally, also physiologically: "she found herself in body and soul a gallant young man, like to the other sons of emperors, only braver and handsomer. ${ }^{31 "}$

On the level of folk narratology, another justification for the heroine's transition to the diametric gender and sex stems from a logic of exclusion. As long as all feminine attributes fall into lliane's possession, the androgynous character cannot return to femininity and the only option left for her is changing into a man, so that every remnant of womanhood shall be forever cauterized from her psyche. As a parenthesis, there are multiple onomastic variations of the feminine prototype in Romanian folk and fairy tales, among which lleana Cosânzeana is the most widely circulated, followed by lleana Sâmziana, as in Ispirescu's text. By any name, these llianes are isotopic and check all the items on the list of the Romanian heroine's attributes, as outlined by Viorica Nișcov: "mainly, she is not only passive, but also devoid of any spiritual consistency, for she is rather the symbol of an idea: the idea

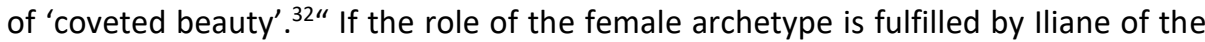
Golden Tresses in the work here analyzed, the only element missing from the fairy tale equation is her masculine counterpart, Prince Charming (known in Romanian as Făt-Frumos). Under these circumstances, it is forbidden to return to the biologically given (female) sex; the emperor's daughter cannot exist as before the initiation. Instead, what is called for is a literal change of sex, not just of gender, in order to neutralize homoerotic notes in the relationship between lliane and the girl in disguise, coupled with filling the above discussed void in the narrative architecture.

Additionally, the necessity of cross-dressing is supported from a mythoantrhropological point of view, for transgressing one's own condition through the act of travesty is frequently used as a ritualistic practice in the stages leading up to marriage, fairly common in primitive communities. To put it as simply as possible, the neophyte is required to simulate and experience the opposite sexual state as a prerequisite for acquiring access to sexuality. A growing body of literature has offered a wide variety of examples of dress exchanges between the sexes specifically with this aim, ranging from bridal customs in antiquity to the quasi-orgiastic European carnival. ${ }^{33}$ Correlated with the "Iliane of the Golden Tresses" tale, these aspects assert the need for the heroine to incorporate both sexes at once through

\footnotetext{
30 Maja Pan, "Introduction to the Analysis of Gender," 169.

${ }^{31}$ Petre Ispirescu, The Foundling Prince, 281.

32 Original text: "e îndeobște nu numai pasivă, dar și lipsită de orice consistența sufletească, fiind mai degrabă simbol al unei idei: ideea de "frumusețe rîvnităı" in Viorica Nișcov, $A$ fost de unde $n$-a fost [Once Upon a Time], 74.

${ }^{33}$ See Mircea Eliade, Mephistopheles and the Androgyne or Arnold van Gennep, Rites of Passage.
} 
sartorial means, as it represents a crucial phase of the rite of passage, at the end of the purification process during which the sexual differences are suspended and in preparation for the ending of the formative process. In contrast with most puberty initiatory structures, in which the asexual neophyte is granted access to the sexual category pertaining to their biological sex, assigned at birth (a male neophyte enters male sexual maturity), in this case the transition takes place not so much from adolescence to adulthood as from one sex/gender to the other, in the literal sense of the term "transgender", more precisely from femininity to masculinity.

Turning to the issue of the prototypal couple, the ideal of masculinity is therefore incarnated by the emperor's daughter recently resexualized, satisfying both the reader's expectations in terms of a heteronormative scenario and completing the narrative structure. As previously highlighted, the curse sets in motion the change of sex and equally important, the end of the transformative process is also provoked through the power of words, in particular through the newly acquired name of Prince Charming. Although there is one earlier occurrence of this name in the conflictual episode between the two genii, there the proper noun is employed rather in a generic sense, simply calling any young man, even intended as flattery, to lure the passer-by into helping them resolve the discord: "Prince Charming, come to my deliverance. ${ }^{34 "}$ At that time, the gender confusion - the two genii take her for a lad - is indicative of the fact that the heroine is successfully performing masculine identity, gradually renouncing her past female self, yet without having reached the Prince Charming-state. The symbolic baptism occurs only towards the final stages of the rite to suggest the winning of the honorific title of masculine archetype. ${ }^{35}$

From the last part of the plot, of particular interest is Prince Charming's line, which is relevant for the denouement of the events and, most importantly, it foreshadows the interpersonal dynamics of the newly formed couple. In analogy to the aforementioned tale, "Frumoasa Lumii, Viteaza Lumii" ["The Most Beautiful, the Bravest"], it contains a marriage condition, this time voiced by the princess-turnedprince- and not by lliane, as already observed in other stages of the action: "But understand that in our house it is the cock that speaks and not the hen.' And man that he now was, he ended by saying, 'This is my will!'36" As maintained by Dwight Edwards Marvin in his study on folk sayings, this sort of utterance is nothing more than a mechanism meant to repress the masculine tendencies of the future bride. Perceived as a menace to the household harmony, these overly virile inclinations are comparable to the ridiculousness of a hen imitating a cockcrow, which is viewed as a

\footnotetext{
${ }^{34}$ Petre Ispirescu, The Foundling Prince, 258.

35 Psyche Z. Ready, "She was really the Man She Pretended to be," 54.

36 Petre Ispirescu, The Foundling Prince, 283.
} 
sign of misfortune by premodern communities. ${ }^{37}$ Applied to Ispirescu's text, the animal metaphor obviously reinforces the phallic voltage injected to the recently metamorphosed protagonist, i.e., the princess turned prince. As far as the eponymous character is concerned, throughout the story one can notice a few moments of active involvement- see for example, the episode in which Iliane, with the help of the magical horse, takes revenge against the ill-intentioned emperor by scalding him with boiled mare's milk for taking advantage of the girl-boy. So, despite having proven her ability to escape the passive condition to which she is normally confined, lliane is expected to "lay down her weapons ${ }^{38 "}$ in exchange of becoming Prince Charming's bride. Once such attempts are neutralized, corrected by the husband, patriarchal order is restored.

The gender code operating in this sequence asserts female inferiority in relation to man, recognizing the fact that it is only due to the transfer to masculinity that the girl-boy can unlock such advantages and is granted special treatment in the eyes of traditional moral and social law. Unfortunately, this emphasis on masculine superiority and feminine docility seems to cancel any potentially feminist interpretations one could have issued on the plotline; it is no longer possible to transgress one's gender boundaries. To take it one step further, it is as if the initial feminine and intermediate androgynous stages would have been completely erased and prominence is given only to the end result embodied by the new Prince Charming, as the epitome of Romanian masculine heroism.

In the final analysis, the investigation of the "lliane of the Golden Tresses" tale demonstrates the volatile identity of the emperor's daughter, metamorphosed into a true Prince Charming, since the oscillation between the two gender poles problematizes modern concepts such as gender performativity and corporeality, hereby expressed in the form of a fantastic fairy tale. To synthetize the research process, the analysis of the transference from the biologically assigned sex to the self and body culturally expressed is supported at a textual level by certain narrative details, with attention to the those that tilt the scales either towards femininity (the presence of the older sisters, domestic activities, inherent feminine impulses) or towards masculinity (absent mother figure, paternal authority, the two magic horses and their psychological roles, the presence of the folk female prototype, lliane of the Golden Tresses).

Reconsidering some of my initial hypotheses, the continuous negation of femininity with each trial and obstacle surmounted undoubtedly accentuates in Ispirescu's version the advantages of the contrary gender, i.e., masculinity, in such a

\footnotetext{
37 Dwight Edwards Marvin, The Antiquity of Proverbs: Fifty Familiar Proverbs and Folk Sayings with Annotations and Lists of Connected Forms, Found in All Parts of the World, (New York: G.P. Putnam's Sons, 1922), 125.

38 Original text: "să depună armele" in Adriana Babeți, Amazoanele. O poveste [The Amazons. A Story], (Bucharest: Polirom, 2013), 222.
} 
way that the initiatory journey rather encompasses masculine heroic values, only temporarily "disguised" under the pretext of am empowered female character. Then, during the intermediate phase the girl-boy is suspended, as we have seen before, in a liminal area, carrying androgynous reminiscences by fusing two into one. In this context, the act of cross-dressing marks the possibility to transcend her initial condition - here female sexual identity - in order to recapture the ontological duality prior to sexual differentiation, as in primitive cultural practices, in an anthropological and mythical view. On the other hand, it signifies, in a predominantly psychological approach, the harmonization of the two diametrically opposed sides of the human psyche, reuniting anima and animus. As shown above, the initiatory process aids the neophyte, as a representative of the entire folk community, to reconnect with the primordial form of existence, androgyny, and after this, to become a fully initiated man. What can thus be inferred from this is that the adhesion of the protagonist to masculinity is equivalent with a progress on the ontological scale, i.e., being lifted to a higher state of being, chiefly in monarchic norms which prescribe masculinity. ${ }^{39}$ To add to this, heteronormativity stigmatizes in this case homoerotic pairings, which in turn explains why the fact that the female archetype, lliane, is rescued by no other than a woman - albeit camouflaged as a man - urges the transsexual mutation of the saviour to complete the fairy tale scenario. In short, the ending hastily remediates any potential deviations from the traditional moral code and reprehends androgyny, as it is not endorsed as an admissible social model within folk imaginary; it is acceptable only as a temporary identity, similar to a transition zone through which the character passes to reach something else.

By virtue of the previously examined aspects, the ATU 514 folk motif, as rendered in this Romanian version, does indeed diverge in various places from the formula of folk stories of becoming, notably through the main character's gender fluidity. In an attempt to provide an answer to the thesis question announced at the beginning of this paper- to what extent the girl-boy represents a feminine and/or heroic example- the analysis undertaken reveals rather an initiation into typically male socio-cultural values. This conclusion is reached through a manifold reading methodology, combining mythical, symbolical, anthropological approaches with folk narratology. Regardless of several instances of departure from the prescribed narrative structure, after all, the present text closely reiterates the rites of passage commonly featured in folk and fairy tales which are centred on a male (sex) protagonist performing masculine (gender) social roles. As long as the last moments of the story portray the protagonist as a young emperor, permanently resexualized, it is no longer possible to interpret the emperor's daughter in female coordinates,

\footnotetext{
${ }^{39}$ Maja Pan, "Introduction to the Analysis of Gender," 173.
} 
seeing how the feminine attributes have been categorically abandoned in favour of an initiation into masculinity.

Having determined that, it is perhaps an example of transsexual metamorphosis more than anything else, which overlaps to a large extent with the corpus of traditional formative discourses with a male neophyte. In essence, the story of the cross-dressing daughter is placed somewhere at the confluence between traditional structures and subversive gender/sex discourses. Gender transgression and redefinition nuances hereby discovered represent just one of the many aspects close to current concerns that can in fact be detected even in narratives from the previous paradigms and are worth exploring in subsequent research, as proof of the influence fairy tales still have on today's rhetoric. 